\title{
The Application of Strategic HRM Models to the Case of Vantage Fintech Ltd, New Zealand to Improve Retention of Highly Skilled Employees
}

\author{
Dr. Sheerali Arya ${ }^{* 1}$, Dr. Michelle Guco Simbulan ${ }^{* 2}$ \\ ${ }^{1}$ Lecturer and Research Coordinator, ${ }^{2}$ Business Lecturer \\ Aspire2 International College, New Zealand \\ ${ }^{\text {\#} C o r r e s p o n d i n g ~ A u t h o r ~ E-m a i l: ~ s h e e r a l i . a r y a @ a s p i r e 2 . a c . n z ~}$
}

\begin{abstract}
Human Resource Management (HRM) is said to be a distinct methodology of managing employees wherein the main objective is to achieve and sustain advantage over the competition through strategic use of skilled and committed employees through well planned techniques of organizational culture, vision and mission (Storey, 1995). Strategic Human Resource Management (SHRM) is the formulation and implementation of a Hunan Resource (HR) plan incorporating HR strategies and practices that can give competitive advantage and at the same time is aligned with the corporate strategies of organizations (Kaufman, 2001). According to Wright and McMahan (1992), SHRM involves an organized pattern of deploying human resources and HR activities to reach organizational goals. It has been pointed out that some areas need to be explored further in this field including promoting employee involvement, highlighting diversity, and international HRM (Wright, 1998). The theories of SHRM are vital for successful deployment of HR policies as they form the foundation of an organizations strategies and core objectives. Through a thorough understanding of these theories the managers can seek to administer required procedures for the employees.
\end{abstract}

This paper explored several HRM models that can be aligned to the strategic goals of a semi fictious company called as Vantage Fintech Ltd. The company is a leading bitcoin trading platform in New Zealand and was developed by ex-bankers with backgrounds in computer science, financial engineering, and traditional finance. Having such highly skilled workforce creates challenges for HR as employees are increasingly likely to abandon their employment in favor of other prospects, making it even more challenging for HR to keep the talent pipeline full. The aim of this research is to examine different theories of Strategic HRM like Vroom's Expectancy model, Guest model, Fombrun model (Michigan Model), Harvard model, and Warwick model to provide wholistic practices which can be adopted by the Managers to retain their high skilled employees while keeping in view the strategic goals of the organization.

Some of the key findings of the paper were while employers have traditionally used benefits to attract and retain employees, they are now particularly targeting certain incentives to highly skilled individuals. Some of the key benefits which can be used to retain these employees were health care, retirement plans, leave benefits and flexible work arrangements. These benefits along with a nourishing workplace environment is imperative for personal and professional development of the employees and overall growth of the Company. The Expectancy theory can be applied in improving Vantage Fintech's reward system. The Guest model can be used to integrate strategies in HR functions such as Recruitment and Selection, Training and Performance Appraisal. The Fombrun model can be applicable to improve their compensation programme. The Harvard model can be utilized in organizational development and the Warwick model can be utilized in strategic HR planning. It is therefore recommended to align organizational goals with HR practices by utilizing SHRM models and theories to achieve wealth maximization, improvement of performance and employee retention.

Keywords - Strategic Human Resource Management; Corporate Strategies; Highly Skilled Employees; Employee Involvement.

\section{Introduction}

Vantage Fintech Ltd was established in 2016 in Wellington, New Zealand with the philosophy of enabling customers to send and receive Bitcoins quickly and securely. They developed a secure and simple platform for accessing the broader cryptoeconomy which is both popular and compliant with over 1 million accounts in Australia and New Zealand (Swyftx, 2021). They have played a significant role in increasing general knowledge and adoption of cryptocurrencies through many successful businesses and advocacy for blockchain technology. Their comprehensive suite of goods assists in the development of the cryptoeconomy and increasing economic freedom (Swyftx, 2021). Their focus is on constructing the cryptoeconomy, by making it a more equitable, accessible, efficient, and transparent financial system through a cutting-edge platform for iOS and Android smartphones thus allowing customers to buy, transfer, and manage 
cryptocurrencies as easily and conveniently as possible. The decentralised app is simple enough for beginners to use while giving experts all the power they need to complete transactions and securely access their Bitcoin wallets at any time (Swyftx, 2021).

Given the complex and sensitive nature of their business Vantage Fintech Ltd is required to employ specialist and highly skilled employees. For the business to transact smoothly, sustenance of impeccable operations is imperative, and this is where the Human Resource department's role becomes crucial (Cawrey, 2014). Right from hiring an employee with a required skill set to training them and most importantly to retaining them, the HR needs to adopt a competent approach and focus on the development of their highly skilled employees for a competitive advantage. This approach has to be strategically aligned with Vantage Fintech Ltd's goals and objectives. Hence, Strategic Human Resource Management (SHRM) is a presentable tuning of the Human Resource Management (HRM) to work in accordance with the business objectives, which necessitates an effective and flawless collaboration between upper management and the head of Human Resources (Bailey, Mankin, \& Garavan, 2018). The company acknowledges that employees who are skilled, talented, and dedicated are the foundation of their success. This research examines this critical success factor of retaining highly skilled employees as without them, expansion and staying ahead of the competition is not feasible for Vantage Fintech Ltd. The research also explores multiple HRM models that the HR Head can implement in retaining these employees as that is one of the key objectives that they must commit to in order to preserve their growth and longevity.

\section{Research Problem}

The financial technology (Fintech) industry is on the verge of the next wave of disruption. While they aim to improve and automate the delivery and usage of financial services, they also need to invest in upgrading ageing systems to improve operational effectiveness and customer experience. As a result, they require leaders who can effectively manage change and highly skilled employees who can perform their responsibilities efficiently. The HR's role in Vantage Fintech Ltd has been continuously evolving and has geared towards a more strategic approach enhancing the alignment of $\mathrm{HR}$ practices to strategic organizational goals. This paper aims to answer the following research questions:

- What are the benefits of retaining highly skilled employees?

- What are the different strategic human resource models that can be applicable to financial companies?
- What HR practices can these models be applied to at Vantage Fintech Ltd.?

- How can Vantage Fintech Ltd improve the alignment of their HR practices with their organizational goals?

\section{Literature Review}

\subsection{Background of Fintech Industry}

Financial technology (Fintech) refers to new technology that aims to improve and automate the delivery and usage of financial services. At its core, fintech is used to help organizations, company owners, and individuals better manage their financial operations, processes, and lives by applying specialized software and algorithms that are used on computers and, increasingly, smartphones (Ashta \& Biot-Paquerot, 2018). When the word "fintech" first appeared in the twenty-first century, it was initially focused on the back-end systems of established financial institutions (Cointelegraph, nd). However, there has been a shift to more consumer-oriented services and, as a result, a more consumer-oriented definition. Fintech currently encompasses a wide range of sectors and industries, including education, retail banking, fundraising and nonprofit, and investment management, to mention a few (Wonglimpiyarat, 2017). Fintech also include the creation and use of cryptocurrencies such as bitcoin. While that sector of fintech receives the most attention, the real money is still in the traditional global banking business, which has a multi-trillion-dollar market value.

There are several active areas of fintech innovation including Blockchain technology, such as Ethereum, which keeps a records on a network of computers but does not have a central ledger (Wamba, Kamdjoug, Bawack, \& Keogh, 2020). Smart contracts utilize computer programmes to automatically execute transactions between buyers and sellers. Open banking enables third parties to have access to bank data to build applications that form a connected network of financial institutions and third-party suppliers. Insurtech uses technology to simplify and streamline the insurance sector (Kagan, 2020). Regtech aims to assist financial sector organizations in meeting industry compliance regulations, particularly those pertaining to Anti-Money Laundering (Kagan, 2020). There are also Know Your Customer processes that helps in combatting fraud. Robo-advisors like Betterment uses algorithms to automate investment advice in order to reduce costs and expand accessibility. Lastly, cybersecurity is crucial for preventing cybercrime (Kagan, 2020).

\subsection{Growth of Bitcoin platforms}

Bitcoin's history began with the development and implementation of the alleged pseudonymous Satoshi

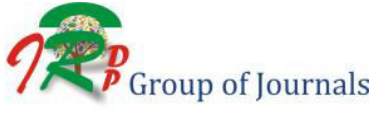


Nakamoto, who incorporated many existing ideas from the cypherpunk group (Cointelegraph, nd). Bitcoin is a cryptocurrency, which is a digital asset meant to function as a medium of exchange and that uses encryption to control its creation and maintenance rather than relying on central authorities. Here the funds are not linked to realworld entities but rather to bitcoin addresses (Cointelegraph, nd). Owners of bitcoin addresses are not expressly named, yet all blockchain transactions are public. Furthermore, transactions can be linked to individuals and businesses using "idioms of use" wherein transactions that spend coins from multiple inputs indicate that the inputs may have a common owner and eventually correlate public transaction data with known information on the owners of specific addresses (Szalay, 2021).

Furthermore, bitcoin exchanges, which sell bitcoins for traditional currencies, may be compelled by law to acquire personal information. To increase financial anonymity, each transaction might establish a new bitcoin address (Szalay, 2021). Wallets and comparable software treat all bitcoins as equivalent, establishing the fundamental level of fungibility. Researchers have pointed out that the history of each bitcoin is recorded and publicly available in the blockchain ledger, and that some users may refuse to accept bitcoins derived from problematic transactions, so undermining bitcoin's fungibility (Böhme, Christin, Edelman, \& Moore, 2015).

Bitcoin has grown rapidly throughout the course of its history to become a prominent currency both online and offline. Some businesses began accepting bitcoin in addition to traditional currencies as early as the mid-2010s (Böhme, Christin, Edelman, \& Moore, 2015). Bitcoins were created as a reward for participating in a process known as mining. They are convertible into other currencies, goods, and services. Bitcoin has been chastised for its usage in unlawful transactions, the vast amount of electricity (and thus carbon impact) required for mining, price volatility, and exchange theft (Haynes \& Yeoh, 2020) At various points, some investors and economists have labelled it a speculative bubble. Others have utilized it as an investment vehicle, despite the fact that various regulatory bodies have issued investor warnings regarding bitcoin (Haynes \& Yeoh, 2020). With the growth of Bitcoin platforms, companies operating in this industry need workers that are highly skilled in technology, finance and even people skills in finding investors. Firms need both hard and soft skills from employees to effectively achieve their operational goals. Hard skills could include an understanding of blockchain, coding, smart contracts, cryptography and security, data analysis, UX design, web development and financial analysis (Ibrahim, Boerhannoeddin, \& Bakare, 2017). Soft skills needed in this industry include creativity, collaboration, persuasion, adaptive to change and willingness to learn (LaborX, 2021).
Finding the right people and retaining these people for the jobs in the finance industry is crucial to the firm's growth.

\subsection{Importance of Retaining Highly Skilled Employees}

Employee retention management entails taking intentional steps to keep employees engaged and focused so that they choose to remain employed and fully productive for the benefit of the firm (Hughes, Robert, Frady, \& Arroyos, 2019). A comprehensive employee retention programme can help to attract and retain essential personnel, as well as reduce turnover and its associated expenses. All these factors contribute to an organization's overall productivity and business effectiveness (Hughes, Robert, Frady, \& Arroyos, 2019). Retaining a quality employee is more efficient than recruiting, training, and orienting a substitute employee of the same caliber (Chapman, 2018). Employee job satisfaction and employee engagement are critical components of employee retention initiatives. The need of addressing these factors is evident, yet doing so requires time, and these activities are frequently put off until another day. However, the return of focusing on employee retention-in terms of improved performance, productivity, employee morale, and work quality, as well as a decrease in turnover and employeerelated problems - is well worth the time and financial effort (Chapman, 2018). The bottom line is that by managing employee retention, firms will retain skilled and motivated workers who genuinely want to be a part of the organization and are committed to making a difference (Chapman, 2018).

\subsection{Strategic HRM Models}

There are several SHRM models proposed that can be applicable in integrating HR practices to the overall strategies of the company such as Vantage Fintech Ltd. These models can help in addressing issues related to retention, turnover and aligning HR goals with the overall organizational goals. Some of these models include the Expectancy theory, The Guest model, The Harvard model, The Fombrun Model (Michigan model), and the Warwick model. The succeeding discussion will elaborate more on each of the models.

\subsubsection{Expectancy Theory}

Victor Vroom proposed the Expectancy theory that is considered as one of the process theories of motivation. This theory consists of two underlying premises: the perceived value of the rewards related to the behavior and the expectation of the person doing the behavior that their actions will be rewarded (Quick, 1988). This model also suggests a more quantitative way to measure motivation. According to the Expectancy theory, motivation can be

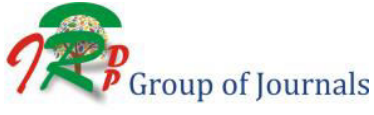


affected by Expectancy, Instrumentality and Valence. Expectancy depicts the subjective probability that the effort exerted will lead to the expected outcome. Instrumentality is the individual's perception that the effort done will lead to rewards or positive outcomes. Valence measures the attractiveness of the rewards or outcomes from the perception of the individual. Using these three variables, the formula of motivation is (Parijat \& Bagga, 2014):

\section{Motivation $=E x I \times V$}

In the work environment, this theory can enhance the value and worth of employees, thereby leading to increased employee commitment and productivity (Quick, 1988). It can facilitate in aligning the personal goals of employees and the organizational rewards or outcomes from work performances. Work outcomes are affected by individual performance. It stresses the importance that employees believe that their efforts lead to high performance and eventually lead to better rewards (Parijat \& Bagga, 2014). Several work criterion measures can be analyzed through the Expectancy theory such as performance, effort, intention, preference and choice. Performance includes productivity, performance ratings, and task performance. Effort could be pertaining to the time spent to do the work, effort ratings, and effort spent in the task. Intention could either be the intent to apply for the job or to leave the job. Preference includes preference for certain jobs or occupation or organisations. Choice refers to the choices in terms of jobs, organisations or turnover (Van Eerde \& Thierry, 1996).

Vroom emphasized in this theory the relationship between employee and organizational goals and the responsibility of the manager to make a working environment supportive of performance. For example, in a bank, new tellers are oriented by the manager regarding the pay system, performance appraisal and criteria to ass the performance of tellers, and performance objectives. Applying the theory, the manager can also ask what types of rewards are valued by the employee and if they are clear regarding their roles and responsibilities in the organization (Mansaray, 2019). This shows the application of the expectancy theory in the work environment.

\subsubsection{The Guest Model}

The Guest model, proposed by David Guest, portrays a sequenced process composing of six components starting with HRM strategies, followed by HRM practices, HRM outcomes, behavioral outcomes, performance outcomes, and lastly with financial outcomes. Financial outcomes highly depend on employee performance. This performance is influenced by employee behavior that is the result of the quality, commitment and flexibility of employees. This behavior is influenced by HR practices and HR practices should be ideally aligned with HR strategies, which also needs to be in congruence with the overall organizational strategies. This model is a combination of soft and hard approaches of HRM. Strategic integration is the hard aspect of this model, while flexibility to adopt to the changing environment can be a combination of hard and soft approaches. It also emphasizes the importance of strategic management in accomplishing organizational goals (Thierry, Modelization of HRM and perspectives for the Cameroon public administration, 2018).

HR practices that this model can be applicable to include selection, training, appraisal, rewards, job design, involvement, and status and security. Specific HR practices that can lead to changes in organization performance include realistic job previews, multi-skilling, regular performance feedback and appraisal, presence of problemsolving and work improvement teams, no compulsory redundancies and minimum voluntary redundancies, flexible job descriptions, profit-related bonuses and individual performance pays, extensive training and welldeveloped induction training, and commitment to single status. HRM strategies should focus on innovation, quality and cost minimization (Lobanova \& Ozolina-Ozola, 2013).

Effective policies on organizational and job design, change management, recruitment and selection, appraisal, training and development, manpower flows, reward system and communication system can lead to HR outcomes such as strategic planning and implementation, commitment, flexibility and adaptability, and quality; and organizational outcomes such as low turnover, absences and grievance, successful change, high job performance and problem solving, and high cost effectiveness (Cakar, Bititci, \& MacBryde, 2003).

\subsubsection{The Harvard Model}

The Harvard model integrated SHRM decisions, organization performance and the business environment. It portrays a more open system wherein strategic HR policies influences organizational functions, focusing on choice and not controlled by stakeholders and situational factors. HRM is viewed in the context of employee influence, supervisory style and organization of work. This model promotes mutuality in terms of goals, rewards, influence and responsibility, which eventually establishes commitment that can result to better performance and human development (Agyepong, Fugar, \& Tuuli, 2010).

This model has two main parts: the human resource system and the map of HRM territory. The human resource system focuses on the areas of administration and labor 
relations. The personnel administration incorporates the rewards, work systems, human resource flow and employee influence. The HRM territory charts the relationship between the external and internal environment and how HRM is linked to these environments (Cakar, Bititci, \& MacBryde, 2003). Breaking the model further, it is composed of five critical components including stakeholders, situational factors, HRM policy choices, HR outcomes, and long-term consequences.

There needs to be a balance of stakeholder interests and tradeoffs among stakeholders are given importance. Situational factors include management philosophy, social values, technology, workforce characteristics, and labor market. HRM policy choices include areas on Employee influence, HR flows, Reward system, and work system. The decisions and actions related to HRM of management is better seen in the light of the interaction between choices and constraints. These policies lead to outcomes such as commitment, competence, congruence, and cost effectiveness. This model focuses more on the soft approach of HRM highlighting the importance of employees in affecting organizational outcomes. Employees are considered as resources and significant stakeholders having their own needs as other stakeholders (Thierry, Modelization of HRM and perspectives for the Cameroon public administration, 2018).

\subsubsection{The Fombrun Model}

The Fombrun model, also known as the Michigan model, focuses on the hard HRM approach viewing employees as resources that can be managed like any other resources. This means that they can be utilized fully and can be acquired cheaply. It is integrating external business strategies with internal HR policies and is driven by market performance, organizational growth and cost minimization (Ivo, 2006). It is one of the simplest models for SHRM focusing on only four factors of HRM including selection, development, performance appraisal and rewards. It covers the interconnection between these functions and how it should be aligned to organizational strategy. It also includes three core elements, which are the mission, strategy and organization structure. However, the Fombrun model does not consider environmental and contingency factors that could have significant impact to the organization (Thierry, Modelization of HRM and perspectives for the Cameroon public administration, 2018). It focuses on the returns of internal stakeholders and is viewed in an individual perspective. The situational factors in the model covers both internal and external organizational aspects. Internal aspects could include mission, strategy and organizational structure, while external aspects are cultural, political and economic aspects (Beer, Boselie, \& Brewster, 2015)

\subsubsection{The Warwick Model}

The Warwick model, proposed by Hendry and Pettigrew, considers the wider context of HRM operations and stressed the range of tasks and skills defining HRM as a strategic function clearly defining structure and strategy. The mission of HRM is heavily normative as it aims to give a diagnosis and proposed solutions. So far, HRM defined the changes happening in its environment and at the same time examining on the gaps in terms of attitudes, coherence, scope and direction (Agyepong, Fugar, \& Tuuli, 2010).

This model is composed of five elements covering the outer context, inner context, business strategy context, HRM context, and HRM Content. It tries to capture the links environmental factors both internal and external and determines how HRM can adapt to the changes happening in its environment. Achieving the alignment of between internal and external context can lead to performance improvement and growth (Thierry, Modelization of HRM and perspectives for the Cameroon public administration, 2018). This model focuses on strategy on change and development of human resource management. Thus, it depicts the interactive relationship between business strategy and HRM (Cakar, Bititci, \& MacBryde, 2003).

\subsection{Key HR Policies in New Zealand applicable to Vantage Fintech Ltd.}

In New Zealand work environment, workplace policies can range from health and safety at work, employee performance, training and development, absenteeism, privacy, etc. These policies are usually in writing. However, there are some policies that are unwritten and goes with the practices and culture of the work environment. It is recommended to update policies consistently and include these unwritten policies. These policies, whether written or unwritten, should be clearly communicated to the employees to avoid misunderstanding and conflicts. From the time the employee signed the employment agreement, employees should be aware of these policies, procedures, rules and guidelines, and these should be aligned with the contents of the employment agreement. Communicating policies can be done individually or collectively, in formal or informal settings. Whatever the approach is, it is important to keep employees up to date regarding any changes to these policies (Employment New Zealand, n.d.).

The employer should consider several factors in writing policies. These includes the company's requirements, history of incidents, employees feedback and insights, policies and procedures of companies in the same industry, local legislations and common laws, fairness of the policies, corporate culture, compliance of employees 
towards such policies, relevant and applicable documents that can be a basis for writing policies. It is important to consider not only the point of view of the employer and management, but of the employees as well. These policies should not be just a piece of work or a display, but it should be realistic and relevant to the nature of operations of the organization. Once the policies are written, it is better to ask for feedback from the employees or the labor union before creating the final version. This can avoid confusion and conflicts of interest between the employer and employees (Employment New Zealand, n.d.). There has been accelerated changes happening in the global business arena along with a rising competition, triggering the need to utilize resources such as human resources to strengthen competitive advantage. This entails a strategic approach in managing human resources and HR practices need to be integrated to the overall strategies of organizations.

Some factors in measuring $\mathrm{HR}$ effectiveness in strategically managing HR practices include staff turnover, number of absences and labor costs. Policies and decisions regarding recruitment and selection, training and development, compensation and benefits, and industrial relations must be are part of the HR planning process and these activities has been the responsibility of the HR team in consultation with the line managers. Some policies such as the workforce expansion or reduction are the main responsibilities of the line manager in consultation with the HR department. In terms of staffing practices, some of the most common methods of selecting employees are application forms, psychometric tests and one-on-one interviews and panel interviews. In terms of training, the professional and technical employees usually have the highest training days compared to manual employees. Hiring an HR specialist from outside of the organization is also one of the practices utilized by organizations particularly on training and development. Increased use of the Human Resource Information System (HRIS) has also been observed particularly in payroll processing and workhours and attendance (Supangco, 2012).

HR effectiveness can also be assessed on how it can affect return on assets and return on equity. It can positively affect financial performance and can lower employee turnover. HR practices on recruitment, training and internal career opportunities can also positively affect employee turnover. Thus, having formal and effective training programs can significantly improve organizational performance. It is also important to consider the fit of HR practices in the different life stages of the organization in terms of viewing the level of impact it has to performance. Although strategic HRM is found to improve performance, further research is needed to determine which specific set of HR practices leads to this consistency (Darwish, Singh, \& Mohamed, 2013).

\subsection{HR Challenges in the Fintech Industry}

It is inevitable that there will be challenges in dealing with human resources as there are complexities of the psychology of how human beings behave in organizations and there are a lot of grey areas that needs to be explored and be addressed in this field of management. There has been a growing importance of $\mathrm{HR}$ as unprecedented changes unfolds in the current times with the COVID-19 pandemic as one of the catalysts for these changes (Caligiuri, Cieri, Minbaeva, Verbeke, \& Zimmermann, 2020). The overall stress that the pandemic brings is one of the challenges faced by HRM having a significant impact on the lives of employees. Particularly in the financial industry, which is stressful enough without the pandemic, financial workers need to cope with the changes including facing volatile markets and the need to work online and increased use of automation (Caligiuri, Cieri, Minbaeva, Verbeke, \& Zimmermann, 2020). There is a growing fear of losing jobs due the changes of working remotely, knowledge of using Artificial Intelligence (AI) and skill matching. This dragged motivation down and management is having a hard time showing workers that they are actually valued in the organization in terms of retaining them and increasing job security (Lytle, 2021).

Another major challenge in the fintech industry is bridging the skills gap as the PWC survey showed that $70 \%$ of the financial services CEO think that growth can be threatened if there is lack of available skills needed in this industry. With the increased prominence of digitalization, there are new skills needed in the financial industry such as data scientists, AI engineers, software engineers and other IT specialists. Another related challenge to this is the shortage of mid-career candidates. There has been a lower inclination for people possessing these skills, qualifications and experience to enter the financial industry due to certain circumstances happening such as the economic downturn. There is a need for the financial industry to improve their reputation and make it more attractive to the labor market (WBR Insights, 2018).

According to PWC report, only $10 \%$ of millennials are planning to work in the financial sector in the long-term. The recruitment and selection process are quite expensive for organisations. Aside from that these new employees would also need to be trained, which costs additional expenses for the company only to find out later on that they will be leaving the company in the short run. There is a need for organisations to implement retention policies and ensure career growth of these employees to establish loyalty and long-term employment in the company (WBR Insights, 2018).

Providing for a company culture that is aligned with the culture and values of the employees is also another

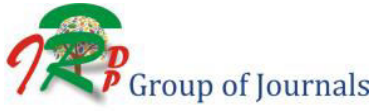


challenge that the financial industry is facing. Providing competitive compensation is not enough to ensure employee motivation, engagement and retention. If the values and practices of the company are not in line with that of the personal values of the employees, then this will not work. For example, employees who value work-life balance will prefer companies who also value this (WBR Insights, 2018). With these challenges in mind, there is a need to examine the alignment of Vantage Fintech's overall strategic goals and their HR practices. This alignment can help them overcome hurdles and face risks that they will be facing in a rapidly changing global environment.

\section{Research Methodology}

The researchers have relied on secondary data collection for the purpose of this research paper due to the confidential nature of the content. This research utilizes descriptive method by gathering information about the strategic HRM models and HR practices from secondary sources. Sources of information includes company websites, research journal articles, company annual report, and scholarly papers. The researchers also checked articles and journals from EBSCO library database which had key research material. This repository held vital information and documents from which data was extracted. The researchers investigated thoroughly these various sources of information to ensure that the criteria of reliability, suitability and adequacy are maintained. framed:

Based on the research, the following objectives were

- To analyze the importance of strategic Human Resource Management model in a Fintech Company.

- To recommend a suitable Human Resource Management model for development of employees and Company.

- To recommend suitable strategies for retaining highly skilled employees in a competitive Industry.

\section{Data Analysis and Discussion}

\subsection{Benefits of Retaining Highly Skilled Employees}

Every firm wants to keep their best employees for as long as possible, but high performers are generally the first to leave. This is costly and disruptive to the corporation, as well as to the people on their teams. The HR Head of Vantage Fintech Ltd must analyze following factors to understand reasons why their highly skilled employees may leave.

Overwork is the leading cause of employee turnover, particularly among top performers. When a Company has a high-performing employee, the Manager tend to assign more work to them. There is a distinction between giving an employee more work because they have the expertise and constantly overloading them with extra responsibilities (Mamun \& Hasan, 2017). A good performer does not appreciate being assigned extra work constantly because their peers were unable to accomplish it. The HR must consider granting them a promotion in this scenario or provide a raise. If these are not attainable, a new job title that emphasizes their increased responsibility and puts them on a road to a raise in the near future may suffice (Mamun \& Hasan, 2017).

When best performers are not challenged at work, they get disengaged. They thrive on achieving goals and being pushed out of their comfort zones (Edmondson, 2018). Their Managers must set challenging goals for them to meet and the employees thrive performing stimulating work. The HR must ensure that the work is not a burden and must creatively motivates the employee. They can allow high achievers to work on a project that isn't going well and consider methods to resolve it (Edmondson, 2018).

Highly skilled employees are enthusiastic about their work and endeavor to take the lead on a project or spearhead a new idea (Karadas \& Karatepe, 2019). They want to be able to take advantage of chances and experiment with new ideas at work. If their passion is repressed, and their Manager advises them to focus solely on the responsibilities that have been assigned to them that can have detrimental effect in terms of employee engagement. This has a double impact since if they are inhibited, they are also unlikely to be challenged. If it's not absolutely necessary for your top achievers to follow a specific process, don't compel them to do so. This annoys them since they know they can complete the task at hand while also focusing on their ideas without sacrificing performance (Karadas \& Karatepe, 2019). It shouldn't matter how they acquired their results if the outcome is successful. Allow children to experiment with alternative methods of accomplishing things and to develop their creativity, critical thinking, and problem-solving abilities.

For high performers, development entails more than just learning new abilities; it also entails opportunities to broaden their skill set and apply those skills into new possibilities. Top achievers may disregard skill improvement since they are already gifted. Just because they can do something exceptionally well it doesn't imply they aren't looking for new ways to learn and grow. The HR must provide them with rich growth options, such as shadowing someone in a senior capacity, taking classes to gain a new technical skill, or partnering them with a mentor. These development chances demonstrate that they are valued and cared. It also assists them in developing

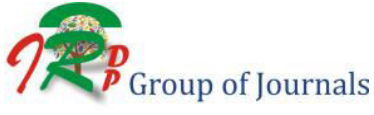


abilities that can lead to a promotion or other career progress.

Timely recognition of efforts is crucial for employees. This is especially crucial for top achievers and highly skilled employees who frequently take on more high-stakes jobs (Stoyanova \& Iliev, 2017). The HR and their Manager can display their appreciation in a basic manner like a welldeserved pat to keep them motivated and take initiate to discover what motivates each individual on a personal level. Tailoring the manner, the appreciation is expressed makes it more genuine and appreciated (Stoyanova \& Iliev, 2017.

Highly skilled employees are well aware of their abilities. If they are not appropriately compensated and provided appropriate benefits, they may quit the job (García-Chas, Neira-Fontela, Varela-Neira, \& CurtoRodríguez, 2019). They may commence begin looking for new opportunities sooner than other employees since they are more confident in their abilities to get another job. It is not only about money when it comes to compensation. The HR also needs to consider other elements that give value to the employee. This can be a title change with increased responsibility, access to senior leadership for mentoring, or perks such as extra vacation days, health benefits, childcare support, free lunches, ESOPs, welcoming environment or a more flexible work schedule (García-Chas, Neira-Fontela, Varela-Neira, \& Curto-Rodríguez, 2019). This will enable retention of employees and providing long term satisfaction to employees.

\subsection{Strategic Human Resource Models and Theories}

The literature gathered delved into several strategic human resource models and theories that can be utilized in aligning the overall goals of finance companies and their HR goals. The table below shows the summary of the different models and theories and what they propose. It also shows which areas of HR it can be applicable.

Table 1: Strategic Human Resource models and theories

\begin{tabular}{|l|l|l|}
\hline $\begin{array}{l}\text { Theory/Mo } \\
\text { del }\end{array}$ & Premise & $\begin{array}{l}\text { Applicable to HR } \\
\text { areas }\end{array}$ \\
\hline $\begin{array}{l}\text { Expectancy } \\
\text { Theory }\end{array}$ & $\begin{array}{l}\text { Behavior is motivated } \\
\text { by expected results and } \\
\text { consequences of actions }\end{array}$ & $\begin{array}{l}\text { Rewards and } \\
\text { compensation, } \\
\text { performance appraisal, } \\
\text { motivation, employee } \\
\text { engagement and } \\
\text { retention }\end{array}$ \\
\hline $\begin{array}{l}\text { The Guest } \\
\text { Model }\end{array}$ & $\begin{array}{l}\text { Hign is strategic based } \\
\text { practices and strategy } \\
\text { Hard and soft } \\
\text { approaches }\end{array}$ & $\begin{array}{l}\text { Selection, training, } \\
\text { appraisal, rewards, job } \\
\text { design, involvement, } \\
\text { and status and security, } \\
\text { HRIS }\end{array}$ \\
\hline $\begin{array}{l}\text { The } \\
\text { Harvard }\end{array}$ & $\begin{array}{l}\text { More open system } \\
\text { Link of HRM with }\end{array}$ & $\begin{array}{l}\text { HR strategic planning } \\
\text { Talent management }\end{array}$ \\
\hline
\end{tabular}

\begin{tabular}{|l|l|l|}
\hline Model & $\begin{array}{l}\text { internal and external } \\
\text { environments HRM } \\
\text { outcomes leading to } \\
\text { long-term consequences } \\
\text { Balance of Stakeholder } \\
\text { interests }\end{array}$ & $\begin{array}{l}\text { Succession planning } \\
\text { Organisational } \\
\text { development and } \\
\text { effectiveness } \\
\text { Learning and } \\
\text { development } \\
\text { HRIS }\end{array}$ \\
\hline $\begin{array}{l}\text { The } \\
\text { Fombrun } \\
\text { Model }\end{array}$ & $\begin{array}{l}\text { Hard approach } \\
\text { (employees are like any } \\
\text { other business } \\
\text { resources) HR strategies } \\
\text { influence overall } \\
\text { business strategies. }\end{array}$ & $\begin{array}{l}\text { Selection, Appraisal, } \\
\text { Development, and } \\
\text { Rewards, productivity }\end{array}$ \\
\hline $\begin{array}{l}\text { The } \\
\text { Warwick }\end{array}$ & $\begin{array}{l}\text { Alignment of business } \\
\text { strategy and HR } \\
\text { practices } \\
\text { External and internal } \\
\text { context } \\
\text { Environmental } \\
\text { influences on HRM } \\
\text { Adaption of HRM to } \\
\text { change }\end{array}$ & $\begin{array}{l}\text { HR strategic Planning } \\
\text { HRIS } \\
\text { Organisational } \\
\text { development and } \\
\text { effectiveness }\end{array}$ \\
\hline
\end{tabular}

Note: This is the summary table created to show the premises of the models and the application of the models to HR practices. Authors' own work.

Based on the table, it can be inferred that the Guest model, Harvard model, the Fombrun model and Warwick model recognized the importance of aligning HR practices and goals to the overall strategies of the organization. The Guest model covers both hard and soft approaches in achieving the alignment. HR practices are based on strategies and can affect performance of employees. The Harvard model is more open and considers not just the internal environment, but also the external environment as well. It acknowledges the importance of HRM outcomes as it has long-term consequences to the organization. Since it recognizes both internal and external environments, it tries to achieve a balance of responding to different stakeholders not only those within the organization but external stakeholders as well. The Warwick model focuses on the different environmental forces that influence HRM and the processes of change happening in the environment that can affect HR strategies and practices. Both the Guest model and the Warwick model addresses change and how firms can be adaptable to change in terms of their strategies and HR practices. While the Fombrun model focuses more on the hard approach, but still recognizes the relationship between HR practices and overall organizational goals.

Although the Expectancy theory does not directly highlight the relevance of the alignment of the HR practices to strategic goals, it paved the way to aligning personal goals of employees to overall goals of the organization. It is quite significant in providing effective compensation programmes and reward systems as well as a more integrated performance management system.

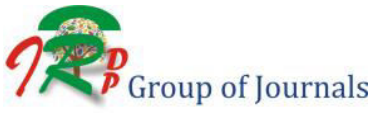




\subsection{Strategic HR models applicable to HR practices at Vantage Fintech Ltd.}

Several models and theories above can be applicable to a financial company such as Vantage Fintech Ltd. in achieving the alignment of their HR practices with their overall strategies. Fintech companies such as Vantage Fintech Ltd. aims to cater to the growing and changing needs to the finance industry such as automated and faster financial transactions, real-time data, convenience and ease of undertaking financial transactions, greater reach of markets, and responding to the varying needs of customers in terms of financial services. They aim to be both economical in terms of lower cost of operations, and effective in providing services to a wide range of users. With these goals in mind, the HR function has a significant role to play in formulating and implementing strategies to achieve these objectives. Table 2 shows how some of the HR models discussed previously can be applicable to specific HR practices of Vantage Fintech Ltd.

Table 2: Strategic HR theories/models applied to the HR practices of Vantage Fintech Ltd.

\begin{tabular}{|c|c|c|}
\hline $\begin{array}{l}\text { Theory/ } \\
\text { Model }\end{array}$ & $\begin{array}{c}\text { HR area } \\
\text { applied to }\end{array}$ & Applied to Vantage Fintech \\
\hline $\begin{array}{l}\text { Expectan } \\
\text { cy theory }\end{array}$ & Reward system & $\begin{array}{l}\text { Rewards based on personal } \\
\text { goals, interests, and wants of } \\
\text { employees } \\
\text { i.e. knowledge-based rewards } \\
\text { such as training for hard skills or } \\
\text { access to updates to recent } \\
\text { technological developments }\end{array}$ \\
\hline $\begin{array}{l}\text { The } \\
\text { Guest } \\
\text { model }\end{array}$ & $\begin{array}{l}\text { Main } \\
\text { functions of } \\
\text { recruitment and } \\
\text { selection, } \\
\text { training and } \\
\text { performance } \\
\text { appraisal }\end{array}$ & $\begin{array}{l}\text { Incorporating company's } \\
\text { strategies in the HR functions: } \\
\text { Methods utilized can attract the } \\
\text { right people for the job and job } \\
\text { design aligns to the strategic } \\
\text { initiatives of the company. } \\
\text { Instead of relying on paper tests } \\
\text { and interviews only, they can } \\
\text { also have practical evaluations } \\
\text { and their own school within the } \\
\text { company to train people and } \\
\text { determine which ones are really } \\
\text { qualified for the job. }\end{array}$ \\
\hline $\begin{array}{l}\text { Fombrun } \\
\text { model }\end{array}$ & Compensation & $\begin{array}{l}\text { As this company needs highly } \\
\text { skilled people, they need to give } \\
\text { attractive and competitive } \\
\text { compensation that matches or } \\
\text { even exceeds what the other } \\
\text { companies in the industry are } \\
\text { offering. Employees should be } \\
\text { viewed as those that can } \\
\text { contribute intellectual wealth to } \\
\text { the company. }\end{array}$ \\
\hline $\begin{array}{l}\text { Harvard } \\
\text { Model }\end{array}$ & $\begin{array}{l}\text { Organisational } \\
\text { development }\end{array}$ & $\begin{array}{l}\text { The company should consider } \\
\text { internal and external } \\
\text { stakeholders, interests in }\end{array}$ \\
\hline
\end{tabular}

\begin{tabular}{|l|l|l|}
\hline & & $\begin{array}{l}\text { building, modifiying and/or } \\
\text { developing the structure, form } \\
\text { and purpose of the organization. } \\
\text { Commitment of all employees } \\
\text { can only be achieved if ther are } \\
\text { consultations and } \\
\text { communications with the } \\
\text { stakeholders regarding } \\
\text { organizational changes. }\end{array}$ \\
\hline $\begin{array}{l}\text { Warwick } \\
\text { model }\end{array}$ & $\begin{array}{l}\text { HR strategic } \\
\text { planning }\end{array}$ & $\begin{array}{l}\text { In formulating HR strategies, } \\
\text { the company should consider } \\
\text { both internal and external } \\
\text { environments. } \\
\text { environment would be the labor } \\
\text { market (supply and demand), } \\
\text { labor laws and regulations, } \\
\text { economic forces such as rate of } \\
\text { unemployment, environmental } \\
\text { forces and cultural factors. }\end{array}$ \\
\hline
\end{tabular}

Note: This table is created to show the application of the models to different HR practices at Vantage Fintech Ltd. Authors' own work.

The Expectancy theory is a classical approach that can lead to increased motivation and productivity of employees and is quite applicable to the recruitment, training, compensation, and promotion functions at Vantage Fintech Ltd. The guest model recognizes the importance of hard and soft approaches in managing human resources and the Vantage Fintech should strike a balance between these two approaches to ensure that HR objectives are met. In the strategic perspective, these theories can serve as an anchor in establishing HRM policies and processes in that are aligned with the overall strategic direction of Vantage Fintech Ltd.

The Expectancy theory of Vroom is applicable at different stages in the Vantage Fintech Ltd where Ms. Julia worked as a Finance Manager. It started right from the recruitment stage wherein she informed the HR manager about the requirement of an employee in her department. The HR manager would then develop a strategy to draw best candidates based on their qualifications and experience. They would give first preference to vintage employees currently working in the Company. For this, a forum like Open Job Posting was held to attract eligible employees from within the Company. This method of internal transfers or promotions is based on Expectancy Theory as it supported their employee retention policy. By applying this theory, both the goals of career growth of an employee and expectations of HR were fulfilled. Next, during the Interview stage the Expectancy theory would become evident from both sides of desk. The interviews were held jointly by the HR Manager and Ms. Julia. On one hand Interviewees expected to impress them by showcasing their expertise and on the other hand the Interviewers had to determine whether the candidate would be a fit in their

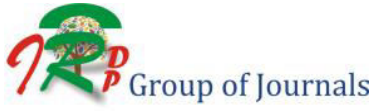


Company. Once the employee was selected and offered a job, he would put best efforts in his performance and prove himself to be worthy of Company's recognition and reward These responses were a part of employee's expectations, and the Company acknowledges that the quality of his work would be relative to the response level expected by the employee for his performance. From this example, the Guest model can also be integrated as it can assist in integrating strategies in the different HR practices mentioned.

Another relevant HRM model applicable to the Company during various phases of functioning is the Guest Model. The guest model, proposed by David Guest, suggests four components that can lead to organizational effectiveness. These components are strategic integration, flexibility, high commitment, and quality of managing human resources. This model also covers two approaches including hard and soft approaches to HRM. The strategic integration is part of the hard approach. Flexibility and quality could both be hard and soft approaches (Thierry, 2018). While high commitment would be part of the soft approach to HRM. Improving the alignment of Vantage Fintech Ltd. HR practices with their organizational goals

What can be inferred in the previous discussion is that strategic HR models, supported with the Expectancy theory can be utilized by Vantage Fintech Ltd. to integrate overall strategic goals in HR practices. They are probably in the process of working towards their goals as a company.

Fig.1: Alignment of HR practices and organizational goals through SHRM models and theories

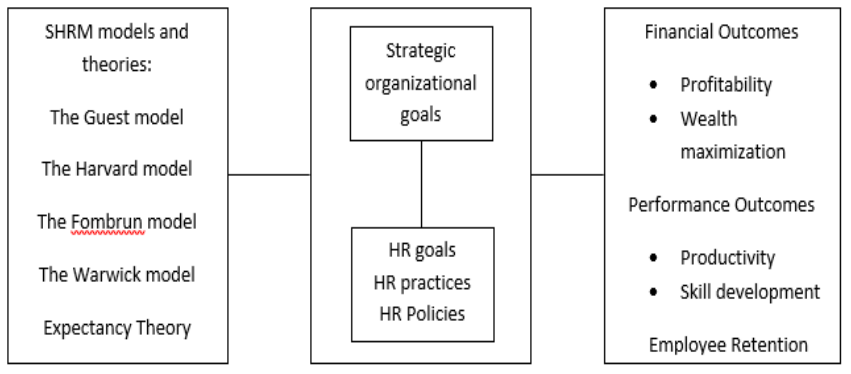

Note: This model was created to show the relationship of the variables discussed. Authors' own work

Through the application of the SHRM models and theories, they can be more aware on what they should focus and what adjustment and further improvements are needed to achieve wealth maximization and growth and development of talent and skills and retention and loyalty of employees.

\section{Conclusion}

HRM, like every other department, is confronted with critical difficulties. Different cultural habits collide with each other at the workplace, much as cross-cultural interaction, which may be viewed as the most significant barrier in any organization, and here is where strategic HRM comes in to play and overcome such challenges (Chang-Howe, 2019). Because New Zealand is a multicultural nation HR departments here take all relevant measures to encourage employees, which makes the working environment pleasant for the employees. The change in ownership of a corporation can sometimes distract employees' attention because it can result in a shift in the corporate environment (Antony, 2018). Advances in technology are also a critical factor that provide a significant challenge to HRM these days, as some employees are comfortable with technology while others struggle to get acclimated to it.

The fundamental pillars on which Strategic Human Resource Management is based can be classified as follows: humans should not be considered as resources alone, but as a vital asset for the organization with the ability to give the essential competitive edge. Employees are the main players in the organization, as they are the ones who actually execute the necessary changes and contribute to the achievement of business objectives. Every single change (regardless of magnitude) is only feasible if effective longterm planning is in place, followed by flawless implementation with all due regard for organizational objectives (Antony, 2018). The primary and most productive goal of strategic HRM is to focus on the different beneficial ways in which the organization can gain a competitive advantage in the market. The strategic HRM models can be used as tools to achieve this goal. But there is a need to dig deeper into the other aspects that can have an impact to this alignment (Bailey, Mankin, \& Garavan, 2018). As the world progresses into the future, HRM will be continually evolving and should be ready to respond to the changes of the times.

\section{References}

[1] Agyepong, S., Fugar, F., \& Tuuli, M. (2010). The applicability of the Harvard and Warwick models in the development of human resource management policies of large construction companies in Ghana. West Africa Built Environment Research (pp. 527-528). Accra, Ghana: WABER.

[2] Antony, M. R. (2018). Paradigm shift in employee engagement-A critical analysis on the drivers of employee engagement. International Journal of Information, Business and Management, 10(2), 32-46.

[3] Ashta, A., \& Biot-Paquerot, G. (2018). FinTech evolution: Strategic value management issues in a fast changing industry. Strategic Change, 27(4), 301-311.

[4] Bailey, C., Mankin, D., \& Garavan, T. (2018). Strategic Human Resource Management. Oxford University Press.

[5] Beer, M., Boselie, P., \& Brewster, C. (2015). Back to the future: Implications for the field of HRM of the multistakeholder perspective proposed 30 year ago. Human Resource Management, 429-430.

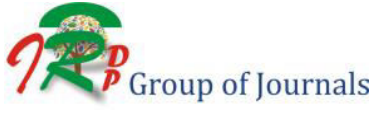


[6] Böhme, R., Christin, N., Edelman, B., \& Moore, T. (2015). Bitcoin: Economics, Technology, and Governance. The Journal of Economic Perspectives, 29(2), 213-238.

[7] Cakar, F., Bititci, U., \& MacBryde, J. (2003). A business process approach to human resource management. Business Process Management Journal, 192-197.

[8] Caligiuri, P., Cieri, H. D., Minbaeva, D., Verbeke, A., \& Zimmermann, A. (2020). International HRM insights for navigating the COVID-19 pandemic: Implications for future research and practice.

[9] Cawrey, D. (2014). Markets : CoinDesk Beta. Retrieved from CoinDesk Beta: https://www.coindesk.com/markets/2014/08/05 /bridging-the-talent-gap-in-the-bitcoin-industry/

[10] Chang-Howe, W. (2019). The challenge of HR integration: a review of the M\&A HR integration literature. Journal of Chinese Human Resource Management.

[11] Chapman, J. (2018). Gaining a talent advantage: How to win candidates from the interview through onboarding and keep them for years. Strategic Finance, 100(3), 44-52.

[12] Cointelegraph. (nd). The history of Bitcoin: When did Bitcoin start? Retrieved from Cointelegraph : The future of money: https://cointelegraph.com/bitcoin-for-beginners/the-history-ofbitcoin-when-did-bitcoin-start

[13] Cointelegraph. (nd). What is Bitcoin blockchain? A guide to the technology behind BTC. Retrieved from Cointelegraph : The future of money: https://cointelegraph.com/bitcoin-for-beginners/howdoes-blockchain-work-a-beginners-guide-to-blockchain-technology

[14] Darwish, T., Singh, S., \& Mohamed, F. (2013). The Role of Strategic HR Practices in Organisational Effectiveness: An Empirical Investigation in the Country of Jordan. International Journal of Human Resource Management, 3343-3362.

[15] Edmondson, A. C. (2018). The fearless organization: Creating psychological safety in the workplace for learning, innovation, and growth. John Wiley \& Sons.

[16] Employment New Zealand. (n.d.). What are workplace policies? Ministry of Business, Innovation and Employment: https://www.employment.govt.nz/workplace-policies/what-areworkplace-policies/

[17] García-Chas, R., Neira-Fontela, E., Varela-Neira, C., \& CurtoRodríguez, E. (2019). The effect of political skill on work role performance and intention to leave: A moderated mediation model Journal of Leadership \& Organizational Studies, 26(1), 98-110.

[18] Gill, C. (1999). Use of hard and soft models of HRM to illustrate the gap between rhetoric and reality in workforce management. Working Paper, 4

[19] Haynes, A., \& Yeoh, P. (2020). Cryptocurrencies and Cryptoassets: Regulatory and Legal Issues. Taylor \& Francis.

[20] Hughes, C., Robert, L., Frady, K., \& Arroyos, A. (2019). Managing technology and middle-and low-skilled employees: Advances for economic regeneration. Emerald Group Publishing.

[21] Ibrahim, R., Boerhannoeddin, A., \& Bakare, K. K. (2017). The effect of soft skills and training methodology on employee performance. European Journal of Training and Development.

[22] Ivo, A. M. (2006). Best Perspectives to human resource management Academia.

[23] Kagan, J. (2020). Financial Technology - Fintech. Investopedia: https://www.investopedia.com/terms/f/fintech.asp

[24] Karadas, G., \& Karatepe, O. M. (2019). Unraveling the black box: The linkage between high-performance work systems and employee outcomes. Employee Relations.

[25] Kaufman, B. E. (2001). The theory and practice of strategic HRM and participative management Antecedents in early industrial relations. Human Resource Management Review, 507.

[26] LaborX. (2021). Blog. LaborX: https://laborx.com/blog/ cryptocurrency-job-skills

[27] Lobanova, L., \& Ozolina-Ozola, I. (2013). Comparative evaluation of the practical areas of human resource management in Lithuania and Latvia. Procedia Social and Behavioral Sciences, 609.
[28] Lytle, T. (2021, March 9). HR magazine Spring 2021. SHRM: https:// www.shrm.org/ hr-today/ news/ hr-magazine/ spring2021/ pages/top-hr-challenges-in-the-financial-services-industry.aspx

[29] Mamun, C. A., \& Hasan, M. N. (2017). Factors affecting employee turnover and sound retention strategies in business organization: A conceptual view. Problems and Perspectives in Management, 15(1), 63-71.

[30] Mansaray, H. E. (2019). The Role of Human Resource Management in Employee Motivation and Performance-An Overview. Budapest International Research and Critics Institute, 189

[31] Parijat, P., \& Bagga, S. (2014). Victor Vroom's Expectancy Theory of Motivation - An Evaluation. International Research Journal of Business and Management, 2-3.

[32] Quick, T. L. (1988). Expectancy Theory in Five Simple steps. Training and Development Journal, 30.

[33] Storey, J. (1995). Human Resource Management: A Critical Text. London: Routlegde.

[34] Stoyanova, T., \& Iliev, I. (2017). Employee engagement factor for organizational excellence. International Journal of Business and Economic Sciences Applied Research, 10(1), 23-29.

[35] Supangco, V. (2012). Strategic HR Practices in Some Organizations in the Philippines. Philippine Management Review, 35-48.

[36] Swyftx. (2021). Crypto Assets: Swyftx. Swyftx: https:// swyftx. $\mathrm{com} / \mathrm{au} / \mathrm{buy} /$

[37] Swyftx. (2021). Features: Swyftx. Swyftx: https://swyftx. com/ $\mathrm{au} /$ features/

[38] Swyftx. (2021). Home: Most Trusted Australian Crypto Exchange. Retrieved from Swyftx: https://swyftx.com/au/

[39] Szalay, E. (2021). Crypto exchanges are booming, for now: Financial Times. Financial Times: https://www.ft.com/ content/d09adf75-9ee9-4c47-9595-69c02113febe

[40] Thierry, A. Z. (2018). Modelization of HRM and perspectives for the Cameron Public Administration. International Journal of Research Science \& Management, 78.

[41] Thierry, A. Z. (2018). Modelization of HRM and perspectives for the Cameroon public administration. International Journal of Research Science \& Management, 78.

[42] Van Eerde, W., \& Thierry, H. (1996). Vroom's Expectancy Models and Work-Related Criteria: A Meta-Analysis. Journal of Applied Psychology, 577.

[43] Walton, R. E. (1985). From control to commitment in the workplace. Harvard Business Review, 77-84.

[44] Wamba, S. F., Kamdjoug, J. R., Bawack, R. E., \& Keogh, J. G. (2020). Bitcoin, blockchain and fintech: a systematic review and case studies in the supply chain. Production Planning \& Control, 31(2-3), 115-142.

[45] WBR Insights. (2018). HR Financial services. HR Finance: https://hrfinance.wbresearch.com/blog/five-key-challenges-facingfinancial-services-hr-recruitment-strategy

[46] Wonglimpiyarat, J. (2017). FinTech banking industry: A systemic approach. Foresight.

[47] Wright, P. M. (1998). Introduction: Strategic Human Resource Management Research in the 21st Century. Human Resource Management Review. 